\title{
Transitional Safeguarding: Presenting the case for developing Making Safeguarding Personal for Young People in England
}

\section{Abstract: \\ Purpose}

This article set out the similarities and differences between the legal frameworks for safeguarding children and adults. It presents the case for developing a Transitional Safeguarding approach to create an integrated paradigm for safeguarding young people that better meets their developmental needs and better reflects the nature of harms young people face.

\section{Design/methodology/approach}

This article draws on the key principles of the Children Act 1989 and the Care Act 2014 and discusses their similarities and differences. It then introduces two approaches to safeguarding: Making Safeguarding Personal (MSP); and Transitional Safeguarding; that can inform safeguarding work with young people. Other legal frameworks that influence safeguarding practices, such as the Mental Capacity Act 2005 and the Human Rights Act 1998, are also discussed.

\section{Findings}

Safeguarding practice still operates within a child/adult binary; neither safeguarding system adequately meets the needs of young people. Transitional Safeguarding advocates an approach to working with young people that is relational, developmental and contextual. MSP focuses on the wishes of the person at risk from abuse or neglect and their desired outcomes. This is also central to a Transitional Safeguarding approach, which is participative, evidence informed and promotes equalities, diversity and inclusion.

\section{Practical implications}

Building a case for developing MSP for young people means that local partnerships could create the type of service that best meets local needs, whilst ensuring their services are participative and responsive to the specific safeguarding needs of individual young people.

\section{Originality}

This article promotes applying the principles of MSP to safeguarding practice with young people. It argues that the differences between the children and adult legislative frameworks are not so great that they would inhibit this approach to safeguarding young people.

\section{Key words:}

adult safeguarding, adolescent, children's safeguarding, emerging adulthood, transition, transitional safeguarding, young people 


\section{Introduction:}

This article presents the case for changing the safeguarding paradigm for young people. We define young people, using the UN description of 'youth', as those aged between 15-24 (United Nations, 2020). In England, children up to and including the age of 17 are subject to child protection processes defined by the Children Act 1989, whilst the safeguarding response for young people over the age of 18 is underpinned by the Care Act 2014. However, neither of these safeguarding systems were designed to meet the developmental needs of young people aged between 15 and 25 (Holmes, 2021). The current child protection system in England has been developed with young children in mind, who predominantly experience abuse and neglect within their family environments (Corby et al, 2012; Department for Education, 2018). This is not the case for adolescents, where they are more likely than younger children to experience harm in extra-familial environments (Firmin, 2020). For adults, safeguarding enquiry duties apply to adults with care and support needs, who are unable to protect themselves from abuse or neglect (Department of Health and Social Care (DHSC), 2020). Most adult safeguarding enquiries involve older adults (NHS Digital 2018).

The resulting binary notion of 'childhood'/'adulthood' within these safeguarding systems stands in stark contrast to many other areas, where services work together to support young people through the transition from childhood to adulthood (for example: leaving care services). This binary notion is reflected in the different service attitudes toward risk; risk management drives a focus on 'risk aversion' in children's safeguarding approaches, whereas 'risk enablement' is a central tenet of adult safeguarding responses (Holmes and Smale, 2018). This article identifies the differences, similarities and challenges arising from the legal frameworks for safeguarding children and adults, and presents a case for developing a Making Safeguarding Personal (MSP) approach to safeguarding young people. We begin by exploring the legal frameworks and principles underpinning children and adult safeguarding in England, before outlining the key tenets of MSP and discussing the implications of further developing and applying these to safeguarding practices with young people.

\section{Background and context:}

In England, both Adult and Children's Social Services have a similar starting point. The Seebohm report of 1968 recommended bringing together all social work services, including child welfare, education welfare, adult welfare and mental health services, to form a single Social Services Department (Donnison, 1969). This was legislated via the Local Authority Social Services Act 1970. However, the development of safeguarding practice, systems and policies in child and family social work and adult social care have been different. 'Modern' child protection developed in the 1970s 
with the death of Maria Colwell in 1973, followed subsequent multiple government enquiries into other child deaths, which have shaped children's safeguarding over the past 50 years (Batty, 2003; Cooper and Whittaker, 2014). Concerns about 'elder abuse' in the 1990's led to a focus on the safeguarding needs of older people (Institute of Public Care, 2013). This culminated in the publication of 'No Secrets' in 2000 , which was a memorandum for practice in adult protection and so was not underpinned by statute (DH 2000). Developments in adult safeguarding have also been influenced by learning from critical incidents and reviews, particularly in institutions, for example the abuse at Winterbourne View (Flynn, 2012), a private hospital for people with learning disabilities, which was one of the drivers for the inclusion of adult safeguarding in the Care Act 2014 (Norrie et al., 2014).

(Insert table 1 here)

The current core statutory (legal) framework for children's safeguarding is the Children Act 1989, which outlines the key duties and responsibilities of local authorities (Department for Education, 2018). Further legislation (see Figure 1) and statutory guidance provide additional detail, including for partner agencies. Chapter 14 of the Care and Support statutory guidance describes the safeguarding adult requirements of the Care Act 2014 (DHSC, 2020) including duties and responsibilities of public sector agencies, including practitioners. This ranges from community responsibilities for prevention to how to undertake a safeguarding enquiry.

\section{Legal differences between children and adult safeguarding}

Whilst there are some similarities in the broad principles underpinning safeguarding practice with children and adults, there are a number of differences.

\section{(insert table 2 here)}

There are six adult safeguarding principles underpinning adult safeguarding (DHSC, 2020). There is straightforward equivalence across children and adult safeguarding for three of these principles: protection; prevention; and partnership. However, these terms may be applied differently in children and adults services. Whilst there are some similarities in content for the other three, empowerment, proportionality, and accountability, the positioning of these principles requires exploration when considering how best to safeguard young people.

Empowerment is a core component underpinning 'personalisation' in adult social care (SCIE 2012) that provides people with choice and control in their lives. It is key to risk enablement as it 
encourages and supports people to make their own decisions. In children's safeguarding, whilst participation is encouraged, it is with the requirement to

'(a) ascertain the child's wishes and feelings regarding the action to be taken with respect to him' and

(b) give due consideration (having regard to his age and understanding) to such wishes and feelings of the child as they have been able to ascertain.'

(Children Act 1989: s. 47(5)(a)

How this is applied to practice with young people is variable. Arguably, 'ascertain(ing) the child's wishes and feelings' is a diluted notion of participation. Article 12 of United Nations Convention on the Rights of the Child states this as every child having the right to express their views, feelings and wishes in all matters affecting them, and to have their views considered and taken seriously (Children and Young Peoples Commissioner Scotland, 2017). Further, practitioner assumptions can influence the amount of participation (Cossar et al., 2011). The Children Act 1989 is clear on this issue, however the implementation of this requirement is often dominated by a paternalistic approach that seeks to eradicate and avoid risk, rather than a participative approach that empowers the young person to make decisions about their own life (Tucker 2016; Diaz et al., 2019)

Proportionality equates to the least intrusive response appropriate to the risk presented. It is key to how risk is managed appropriately in safeguarding practice with adults, and central to the application of the Mental Capacity Act 2005, which provides a statutory framework to empower and protect vulnerable people unable to make their own decisions. The Mental Capacity Act 2005 applies to young people 16 years old and over. In both legal frameworks for children and adults, intervention should only be as much as is necessary to achieve a safeguarding goal. The State must be able to justify intervention. However, whilst in adult safeguarding, proportionality equates to the least intrusive response appropriate to the risk presented, in children's safeguarding, the argument for proportionality is spread across a number of pieces of legislation. The Children Act 1989 has as its key principle, 'the welfare of the child', which includes the 'no order' principle. This has a broader application than proportionality in decision-making in child protection, and unlike adult safeguarding, it is not based solely on the child or adolescent's expressed wishes, even when the adolescent is over 16 and has mental capacity. There are tensions in the intersection of these legislation (Children Act 1989; Mental Capacity Act 2005), which are explored further below. In addition, the Human Rights Act 1998 requires a proportional approach, but the Article 8 right to 
private and family life is a qualified right, meaning that it can be interfered with in order to protect the rights of another or the wider public interest (Brammer, 2015).

Accountability for safeguarding at a strategic level is articulated in the relevant guidance for both children and adult partnerships/Boards. Children's Partnerships aim is to promote interagency cooperation to safeguard and promote the welfare of children in their area (DfE, 2018). Safeguarding Adults Boards aim is to provide assurance that local safeguarding of adults with care and support needs is effective, person-centred and outcome-focussed (DHSC 2020). At a practice level, the way 'accountability' is understood by practitioners differs. The 'I' statement for the 'accountability' principle in adult safeguarding posits: "I understand the role of everyone involved in my life and so do they.' Whilst good practice would determine that routine sharing of information about all aspects of the safeguarding process should be undertaken by practitioners with the young people involved, this does not always occur. Young people should be involved in developing appropriate safeguarding responses to the risks in their lives: these should be personalised and outcome focused, in keeping with MSP (Lawson, 2017). There is evidence that the involvement of young people has considerable value for child protection services and the young people themselves (Cossar et al, 2011; Jobe and Gorin 2012, Warrington, 2016).

Attitudes toward concepts of 'risk' and 'rights' in children and adult safeguarding systems varies. Children's services have developed a more 'risk averse' culture (Munro, 2019), largely linked to public concerns and political reactions following child deaths. Adult services have moved towards a more 'risk enabling' approach, which supports adults to keep themselves safe (Lawson, 2017; White. 2017). This has not always been the case. Writing before the Care Act 2014, Faulkner (2012) asserted that the language used in adult safeguarding to describe risk was influenced by social workers attitudes and assumptions; the absence of services users' voices meant their concerns were not acknowledged and therefore their views on risks in their lives not considered. Practice has changed since the Care Act 2014, with an expectation that people are at the centre of decision-making about their lives and their views inform the safeguarding process and approach to risk (Cooper, 2016).

For anyone over 16 years of age, their mental capacity will also determine the extent to which they are involved in decision-making about their lives. Mental capacity should be assumed unless it is proved otherwise. However, children's social workers' understanding and application of the Mental Capacity Act 2005 is variable, although there are examples of relevant local safeguarding advice (e.g. Kirklees, 2016). Work with young people under 18 remains reliant on the safeguarding framework in the Children Act 1989. 
In terms of safeguarding young people aged $17+$, many young people do not have special educational needs or disabilities (SEND) or mental health difficulties diagnosed before they are 18 (House of Commons Education Committee, 2019), so do not automatically meet the care and support criteria in s. 42 of the Care Act 2014. For example, young people affected by criminal exploitation may not have identifiable care and support needs; and concerns about their 'behaviours' may overshadow their possible needs and inability to protect themselves, which further compounds their vulnerability (APPG, 2017).

Further, in light of the evolving nature of harms and risks for this specific group of young people, including the increase in (and/or increased understanding of) extra-familial harm, these types of harms very much extend beyond 18. Harm may continue irrespective of whether a young person enters or leaves care, and harm from exploitation can arguably fuel a cycle of victim/perpetrator more than many other type of abuse (Home Office, 2019; Cockbain and Olver 2019; McLean et al., 2020). This presents new challenges to child protection and adult safeguarding (Senker et al., 2020; Turner et al., 2019).

Finally, the two safeguarding systems place difference emphasis on 'welfare' and 'wellbeing'. Children's 'welfare' underpins the Children Act 1989, with the paramountcy principle as the central tenet i.e. that the child's welfare is paramount in all decision making. The Children Act 2004 mentions both 'welfare' (s.11 - duty to make arrangements to safeguard and promote welfare) and 'wellbeing' (s. 10(2) mentions making arrangements to improve the wellbeing of children in the local authority's area regarding their social, economic, physical, mental and emotional wellbeing). This also includes protection from harm and neglect. In adult safeguarding, the 'wellbeing' of the adult is central to the Care Act 2014 and fundamental to safeguarding. The objectives of any safeguarding intervention therefore is to promote the person's wellbeing as well as ensure safety from harm or neglect (DHSC 2020, para 14.7).

The statutory guidance accompanying the Care Act 2014 clarifies that safeguarding duties apply to young people aged 18 or older if they are still receiving ongoing support from Children's services, regardless of their level of needs, as long as the section 42 criteria are met (DHSC 2020, para 14.5). However, this could be interpreted in a variety of ways, which means that areas of exploitation and risk may not be considered relevant.

\section{Other relevant legislation - Not a neat fit:}


(insert figure 1 here)

Both safeguarding frameworks interface with other policies and legislation that highlight the confused and contradictory understanding of childhood and adulthood. For example, the Mental Capacity Act 2005 assumes someone has mental capacity from age 16, whilst Child Sexual Exploitation (CSE) and Child Criminal Exploitation (CCE) definitions assert that someone under 18 cannot consent to their exploitation. Specifically, it says, 'the victim may have been sexually exploited even if the sexual activity appears consensual' (Department for Education 2017, p5). The new Domestic Violence (DV) bill definition states that both the person who is carrying out the behaviour and the person to whom the behaviour is directed towards must be aged 16 or over and that both persons must be personally connected. The Home Office DV factsheet says "Abusive behaviour directed at a person under 16 would be dealt with as child abuse rather than domestic abuse" (Home Office, 2020, p1) with no acknowledgment of the complexity of this regarding the definition of CSE. Therefore, a 17 year-old could be simultaneously a victim of DV, and/or CSE, and equally be considered to be able to make an unwise decision, allowing the abuse to continue.

This dichotomy extends to who has agency over key decisions in a young person's life e.g. clinicians should give due regard to a competent child's wishes in respect of medical treatment, but the Mental Capacity Act 2005 only permits those 18 or over to make advanced decisions regarding their treatment or appoint someone as Lasting Power of Attorney. Similarly, whilst those with parental responsibility can determine where a child under 16 resides (even if the circumstances are so restrictive to amount to a deprivation of the child's liberty), a young person aged 16 or over can override parental objections and consent to be accommodated under s20 Children Act 1989 and any restrictive placements (however necessary from a safeguarding perspective) cannot be authorised by those with parental responsibility, so may require applications for judicial approval.

Recent revisions to the wider legal framework that underpins the safeguarding function, e.g. under the Homelessness Reduction Act 2017, encourage practitioners to consider safeguarding risks, engage with young people to identify risks and improve inter-agency cooperation and responses when abuse or neglect has occurred. It remains the case, however, that the complexity of contextual safeguarding risks, the distinctive age dependent application of rights and responsibilities and the divergent pathways for seeking judicial guidance requires a high degree of legal literacy within the safeguarding workforce, for example social workers undertaking safeguarding activities.

In considering the different legal aspects of safeguarding, Justice Munby's (Judge in the Court of Protection, who later became President of the Family Division (2013-18), and a Law Lord) statement 'What good is it making someone safer if it merely makes them miserable?' captures the key 
balancing of different risks, needs and outcomes (Local Authority X v MM \& Anor (No. 1) (2007), para 120). The children and adults safeguarding paradigms address this 'balancing' in different ways.

\section{Making Safeguarding Personal:}

Making Safeguarding Personal (MSP) is an approach to safeguarding adults that focuses on the needs and outcomes that the person experiencing or at risk from abuse or neglect has themselves identified. It emphasises person-centred and outcome-focused practice and aims to achieve improvements in a person's wellbeing as well as safety from the safeguarding process (Lawson, 2017). MSP is underpinned by a Human Rights perspective (Human Rights Act 1988; Equality Act 2010), a collaborative and flexible approach to risk assessment, enabling risk taking as well as responding to and managing risks (White, 2017). It supports resolution of the safeguarding issues and recovery from any trauma experienced by the person (Cooper et al., 2018). Essentially it promotes an approach where safeguarding is done 'with' and not 'to' people in order to achieve meaningful improvement in their lives, and utilises the skills of practitioners, rather than safeguarding being about putting people through a process (Cooper and White, 2017).

The MSP national programme started in 2009 in response to identified weaknesses in safeguarding practice, which were inconsistent with the personalisation agenda in adult social care. Safeguarding work was dominated by processes to establish whether harm was 'substantiated' or not, rather than what the person themselves wished to achieve in terms of their own safety. MSP was tested in a small number of Local Authorities (Klee \& Williams, 2013), before being piloted by a much larger group of Local Authorities, and externally evaluated (Pike \& Walsh, 2015). MSP was then incorporated into the statutory guidance accompanying the Care Act 2014 (DHSC, 2020). Two-thirds of Local Authorities report on the extent to which the persons outcomes have been met through the safeguarding process in the annual voluntary data return to NHS Digital (NHS Digital, 2018; 2019).

Putting MSP into practice means applying the six safeguarding principles outlined above (Lawson, 2017). Practice frameworks, like 'signs of safety' (Turnell and Edwards, 1999), methods, such as restorative justice, and models, such as Family Group Conferencing, can all deliver an MSP approach to safeguarding adults (Stanley, 2017; Gunner, 2017; Taylor \& Tapper, 2017).

As part of the MSP programme, jointly led by the Association of Directors of Adult Social Services (ADASS) and the Local Government Association (LGA), resources were developed to support practitioners to change their safeguarding practices. The MSP toolkit has been updated four times, with the most recent version containing key resources and specific practice tools, which can be 


\section{Reimagining safeguarding for young people - Transitional Safeguarding}

The MSP approach to safeguarding can be used to develop a response for young people that uses the six key principles. This would provide the necessary link between the two safeguarding systems, drawing on the adolescent development knowledge of Children's services colleagues but within an approach that is more responsive to the views of young people and offers a fluid and developmentally-attuned pathway. It is possible to enable young people to share responsibility and decision-making, and move from the 'adult knows best' attitude towards a child, to being treated as an adult with capacity and right to make unwise decisions.

Holmes and Smale (2018) present the case for Transitional Safeguarding: 'an approach to safeguarding adolescents and young adults fluidly across developmental stages which builds on the best available evidence, learns from both children's and adult safeguarding practice and which prepares young people for their adult lives' (Holmes and Smale, 2018, p3). Transitional Safeguarding seeks to span the boundary between the two systems. Whilst meeting the statutory requirements for safeguarding pre-and post the 18-year threshold, the aim of this approach is to incorporate the strengths of each, acknowledging the research evidence that explores the dynamic and heterogeneous developmental needs and behaviours of this age group. A Transitional Safeguarding approach has six key elements: contextual (Firmin, 2020)/ecological; transitional/developmental; and relational; it is evidence-informed; participative; and promotes equalities, diversity and inclusion (Holmes and Allen, forthcoming). One of the compelling links between MSP and Transitional Safeguarding is the framework for a personalised/individualised response that each offers. (insert Figure 2 here)

The young people who may need a Transitional Safeguarding approach have a range of different needs and vulnerabilities to exploitation, abuse or neglect. There are groups of young people who are already known to children's health, social care and educational services, whose safeguarding 
needs may be already identified by those services. They include young people who have care and support needs, who may have physical or learning disabilities or difficulties, autism or mental health problems. This is not to suggest that someone's disability automatically makes them vulnerable to abuse, rather that they are already known to statutory services. Some young people who have had experience of the care system may require ongoing support to keep safe. Some will have transitional arrangements made for them when they turn 18 , so that they continue to receive support until they are 25 (see Cocker et al., 2021). A further group of young people may be known to Youth Justice Services, including young people involved in county lines, criminal exploitation, or modern slavery. Whilst under 18 years of age, their safeguarding needs would be addressed through child protection systems and services (DfE 2018). However, less would be eligible for safeguarding adult services as they are unlikely to be assessed as having 'care and support needs' that affect their ability to protect themselves from abuse or neglect (DHSC, 2020).

All of the above circumstances can exacerbate a young person's vulnerability to exploitation, and make it harder for them to recognise and disclose their abuse, or extract themselves. Yet this may not translate to 'care and support needs'. Further, there may be some young people who are not known to services, or on the periphery, such as those facing homelessness (Neinstein, 2013; PrestonShoot, 2020), or those who do not have diagnosed disabilities, who are particularly at risk of falling through the gaps. They may be known to universal services such as community health via GPs or sexual health clinics; or to voluntary, community or faith groups.

\section{Making Safeguarding Personal and Young People:}

Focusing on the six key elements of the Transitional Safeguarding approach (Holmes and Allen, forthcoming 2021), MSP can offer a number of benefits in effectively safeguarding younger people. Critical to delivering MSP is a person-centred approach: involving the person from the start, asking simple questions so that the process is driven by their wishes and aspirations and they define the outcomes to be achieved (Lawson, 2017; NHS Digital, 2018). MSP is a participative approach to safeguarding adults, building on the 'nothing about me without me' mantra of the disability rights movement (Charlton, 2000) and user-empowerment models (Arnstein, 1969). This is also key to Transitional Safeguarding, acknowledging that young adults have agency, and their developmental needs are individual and personalised to them, not bound only by arbitrary factors such as age. Further, as well as resolving safeguarding challenges in their own lives, MSP advocates participation of people who use services at a strategic level, in Safeguarding Adults Boards (Drey \& Lawson, 2017). This chimes with Warrington's (2016) description of young people's participation being about 
influencing services, community, strategy, research and policy - not just their own care plans. A number of local authorities are beginning to expand this approach, working with young people as key stakeholders in strategic service developments to deliver a Transitional Safeguarding approach (Cocker et al., 2021). This approach builds on previous work to ensure the voices of children and young people influence policy and practice, for example the role of 'children in care' councils (Thomas and Percy-Smith, 2012).

As a personalised approach, all aspects of that individual's situation are acknowledged and taken into account in the safeguarding process, including structural inequalities: good practice in MSP should promote equalities, diversity and inclusion (RiPfA, 2019). Ultimately, MSP is a conversation supported by a process, rather than a process supported by conversations with the person and so relies on positive relationship building by practitioners with the person i.e. relational practice (Lawson, 2017, pp.35-37; Cooper, 2019).

Transitional Safeguarding is an approach that can be delivered through different tools in a way that meets the core requirements of this approach; there are a number of models, methods and frameworks that could support delivery and meet the safeguarding needs of young people. Some of these are the same as those promoted through the MSP programme: signs of safety, restorative justice and mediation, Family Group Conferencing (RiPfA, 2019). Other models and methods relevant to deliver a Transitional Safeguarding approach have emerged from children's safeguarding work. These include: Contextual Safeguarding; Complex Safeguarding (Firmin et al., 2019); and Trauma Informed Approaches (Treisman, 2017). These models and methods emerged from work on areas of safeguarding that have been a focus for Children's services, for example child sexual exploitation (see Scott et al, 2019, p107).

As with MSP, Transitional Safeguarding is not delivered through a particular service configuration. The learning from MSP pilots was that service delivery models do not require standardisation (Pike \& Walsh, 2015). Different young people need joint work between a variety of agencies, in the context of varied legislative structures and frameworks. There are examples of services that have been developed to meet Transitional Safeguarding needs of some young people e.g. Havering has a service configuration that can provide a Transitional Safeguarding approach for care experienced people (see: Wallace and Cocker, forthcoming 2021). Practitioners looking to develop transitional safeguarding approaches can learn from innovations already taking place (see 2021 Special Issue on Transitional Safeguarding in 'Practice: Social Work in Action' Journal).

The outstanding challenge in delivering a Transitional Safeguarding and MSP approach is to ensure that whatever model of service is used, it is able to address the developmental needs of young 
adults (Authors own, forthcoming). This developmental stage, known as 'Emerging Adulthood' (Arnett, 2000), is a stage in-between adolescence and young adulthood where young people are no longer children but do not yet have the responsibilities or experience of social or cultural rituals regarding relationships, work and financial responsibilities that determine much of adult life (Arnett, 2000; authors own, in press 2021). A nuanced and flexible response from services, because of the particular needs and developmental stages of these young people, is required.

\section{Conclusion:}

This article describes the challenges arising from the different legal frameworks for safeguarding children and adults. It shows that the perceived differences in legislative frameworks are not insurmountable. Transitional Safeguarding is an approach to safeguarding that highlights the specific needs and complexities of young people; it is contextual/ecological, developmental and relational. Whilst there are examples of a Transitional Safeguarding approach with some groups of young people in different places, there are limited examples of this approach applying to all young people who may need a safeguarding response. MSP, like Transitional Safeguarding, emphasises that the safeguarding process is participative, done 'with' not 'to' the person, and equalities, diversity and inclusion are addressed through personalised practice. The article argues that as both are approaches to safeguarding, they do not require specific service configurations, but can be delivered through a variety of methods, using different tools, and local service models depending on need. Using MSP to address young people's safeguarding needs could help to meet the 'gap' identified in safeguarding practices for young people aged between 15-25, where empowerment, proportionality and accountability can be patchy. By developing an MSP approach to safeguarding young people, their developmental needs could be better met. However there is still a long way to go to achieve it, particularly where a young person may not be deemed eligible for this support as their needs and risks place them outside of current adult safeguarding remit. 


\section{References:}

All Party Parliamentary Group (2017) APPG on Runaway and Missing Children and Adults: Briefing report on the roundtable on children who go missing and are criminally exploited by gangs. London. Available at:

https://www.missingpeople.org.uk/files/PandR/APPG\%20Missing,\%20Gangs\%20and\%20Exploitation \%20Roundtable\%20Report.pdf

Arnett, J. (2000) 'Emerging Adulthood: A Theory of Development from the Late Teens through the Twenties.' American Psychologist 55(5), pp469-480

Arnstein S.R. (1969) A Ladder Of Citizen Participation, Journal of the American Institute of Planners, $35: 4,216-224$.

Batty, D. (2003) 'Catalogue of cruelty'. The Guardian Newspaper 27 January 2003. Available at: https://www.theguardian.com/society/2003/jan/27/childrensservices.childprotection

Brammer, A. (2015) Social Work Law. Harlow, Pearson.

Charlton, J.I. (2000) Nothing About Us Without Us: Disability, Oppression and Empowerment, Berkeley, University of California Press

Children and Young Peoples Commissioner, Scotland (2017), UNCRC Article 12, Available at https://cypcs.org.uk/rights/uncrc/articles/article-12/

Cockbain, E. and Olver, K. (2019) 'Child Trafficking: Characteristics, complexities and challenges'. In I. Bryce, Y. Robinson and W. Petherick (eds) Child abuse and neglect. London: Academic Press, pp95116

Cocker, C., Cooper, A., and Holmes, D. (2021) Transitional safeguarding: Transforming how adolescents and young adults are safeguarded. British Journal of Social Work. Advance Access

Cocker, C., Cooper, A., and Holmes, D (2021) 'Transitional Safeguarding: Bridging the Gap between children's and adult safeguarding responses' in D. Holmes (ed) Safeguarding Adolescents: Risk, Resilience, Rights and Relationships. London, Jessica Kingsley Publishers.

Cooper, A. (2016) Making Safeguarding Personal Temperature Check, London Association of Directors of Adults Social Services

Cooper, A (2019) Myths and realities' about Making Safeguarding Personal; London, Association of Directors of Adults Social Services \& Local Government Association

Cooper, A. Cocker, C. and Briggs, M. (2018) 'Making Safeguarding Personal and Social Work Practice with Older Adults: Findings from Local-Authority Survey Data in England'. British Journal of Social Work 48, pp1014-1032

Cooper, A. \& White, E. (2017) (eds), Safeguarding Adults Under the Care Act: Understanding Good Practice, London, Jessica Kingsley Publications,

Cooper, A. and Whittaker, A. (2014) 'History as tragedy, never as farce: Tracing the long cultural narrative of child protection in England'. Journal of Social Work Practice. 28(3), pp251-266.

Corby, B., Shemmings, D., \& Wilkins, D. (2012) Child Abuse: An Evidence Based of Confident Practice (4th edition). Berkshire, Open University Press.

Cossar, J., Brandon, M. and Jordan, P. (2011) 'Don't Make Assumptions': Children's and Young People's Views of the Child Protection System and the Messages for Change, London, Office of the Children's Commissioner. 
Department for Education (2018) Working Together to Safeguard Children. London, Department for Education.

Department for Education (2017) Child sexual exploitation Definition and a guide for practitioners, local leaders and decision makers working to protect children from child sexual exploitation. London, Department for Education. Available at:

https://assets.publishing.service.gov.uk/government/uploads/system/uploads/attachment_data/file 1591903/CSE Guidance Core Document 13.02.2017.pdf

Department of Health and Social Care (2020) Care and support statutory guidance, updated $24^{\text {th }}$ June 2020. Available at: https://www.gov.uk/government/publications/care-act-statutory-guidance/careand-support-statutory-guidance

Department of Health (2000) No secrets: Guidance on developing and implementing multi-agency policies and procedures to protect vulnerable adults from abuse, London, Department of Health

Diaz, C., Pert, H., and Thomas, N.P. (2019) 'Independent Reviewing Officers' and social workers' perceptions of children's participation in Children in Care Reviews'. Journal of Children's Services 14(3): pp162-173

Donnison, D. V. (1969). The Seebohm Report and Its Implications. International Social Work, 12(2), pp11-17.

Drey, R. \& Lawson, J. (2017) Making Safeguarding Personal Supporting increased involvement of service users, London ADASS \& LGA

Faulkner, A (2012) The Right To Take Risks: Service Users' Views of Risk in Adult Social Care. Joseph Rowntree Foundation. Available at:

https://www.jrf.org.uk/sites/default/files/irf/migrated/files/right-to-take-risks-faulkner.pdf

Firmin, C. (2020) Contextual Safeguarding and Child Protection: Rewriting the Rules. Abingdon, Routledge

Flynn, M (2012) Winterbourne View Hospital: A Serious Case Review. South Gloucestershire, South Gloucestershire Safeguarding Adults Board. Available at:

https://hosted.southglos.gov.uk/wv/report.pdf

Gunner, J. (2017) 'Working towards Recovery and Resolution, including Mediation and Restorative Justice' in Cooper, A. and White, E. (eds), Safeguarding Adults Under the Care Act: Understanding Good Practice, London, Jessica Kingsley Publications, pp. 74-90.

Holmes, D. (2021) Safeguarding Adolescents Risk, Resilience, Rights and Relationships. London, Jessica Kingsley

Holmes and Allen (forthcoming - 2021) 'The Case for Transitional Safeguarding'. Practice: Social Work in Action: Special Issue on Transitional safeguarding.

Holmes, D. and Smale, E. (2018) Mind the Gap: Transitional Safeguarding-Adolescence to Adulthood. Dartington, Research in Practice.

Home Office (2020) Domestic Abuse Bill 2020: Statutory Definition of Domestic Abuse. London, Home Office. Available at:

https://assets.publishing.service.gov.uk/government/uploads/system/uploads/attachment data/file 1909878/Statutory Definition of Domestic Abuse- AUG 2020 .pdf

Home Office (2019) Child Exploitation Disruption Toolkit: Disruption Tactics. London, Home Office. Available at: 
https://assets.publishing.service.gov.uk/government/uploads/system/uploads/attachment data/file 794554/6.5120 Child exploitation disruption toolkit.pdf

House of Commons Education Committee (2019) Special educational needs and disabilities: First Report of Session 2019. London, House of Commons. Available at:

https://publications.parliament.uk/pa/cm201919/cmselect/cmeduc/20/20.pdf

Institute of Public Care (2013) Evidence Review - Adult Safeguarding. London, Skills for Care.

Available at: https://ipc.brookes.ac.uk/publications/pdf/Evidence Review - Adult Safeguarding.pdf

Jobe, A. and Gorin, S. (2013) "If kids don't feel safe they don't do anything': young people's views on seeking and receiving help from Children's Social Care Services in England', Child \& Family Social Work., 18 (4). pp. 429-438.

Kirklees Safeguarding Children Partnership (2016) Guidance on use of Mental Capacity Act 2005 re 16/17 year olds. Available at:

https://www.kirkleessafeguardingchildren.co.uk/managed/File/Guidance\%20on\%20use\%20of\%20M ental\%20Capacity\%20Act\%202005.pdf

Klee, D. \& Williams, C. (2013) Making Safeguarding Personal, London, Local Government

Association. Available at:

https://www.scie.org.uk/publications/misc/makingsafeguardingpersonal.pdf

Lawson, J. (2017) 'The Making Safeguarding Personal approach to practice', in Cooper, A. and White, E. (eds), Safeguarding Adults Under the Care Act: Understanding Good Practice, London, Jessica Kingsley Publications, pp. 20-39.

Local Authority X v MM \& Anor (No. 1) [2007] EWHC 2003 (Fam), (2008) 11 CCL Rep 119, [2009] 1 FLR 443, [2008] Fam Law 213, [2008] 3 FCR 788. Available at:

http://www.bailii.org/ew/cases/EWHC/Fam/2007/2003.html

McLean, R., Robinson, G. and Densley, J.A. (2020) County Lines: Criminal networks and Evolving Drug Markets in Britain. Cham, Switzerland: Springer.

Munro, E. (2019) 'Decision-making under uncertainty in child protection: Creating a just and learning culture'. Child and Family Social Work, 24, pp123-130.

Neinstein L.S. (2013) The new adolescents: An analysis of health conditions, behaviors and risks and access to services among emerging adults. Available online:

https://eshc.usc.edu/thenewadolescents/doc/TheNewAdolescents_Final_Locked.pdf

Norrie, C Stevens, M. Graham, K. Manthorpe, J. Moriarty, J. Hussein, S. (2014) 'Investigating models of adult safeguarding in England - a mixed methods approach', Journal of Adult Protection. 16(6), pp377-388.

NHS Digital (2018) Safeguarding Adults, England, 2017-18, NHS Digital, Available at https://digital.nhs.uk/data-and-information/publications/statistical/safeguarding-adults

NHS Digital, (2019), Safeguarding Adults, England, 2018-19, NHS Digital, Available at https://digital.nhs.uk/data-and-information/publications/statistical/safeguarding-adults/annualreport-2018-19-england/supporting-information

Pike, L and Walsh, J (2015) Making Safeguarding Personal 2014/15 Evaluation Report. London, Local Government Association

Preston-Shoot, M. (2020) Adult Safeguarding and Homelessness, A briefing on positive practice London, ADASS \& LGA. Available at: https://www.local.gov.uk/adult-safeguarding-andhomelessness-briefing-positive-practice 
Research into Practice for Adults (RiPfA) (2019), Making Safeguarding Personal Toolkit: Practice Toolkit Handbook, London, Association of Directors of Adult Social Services and Local Government Association. Available at:

https://www.local.gov.uk/sites/default/files/documents/MSP\%20Toolkit\%20Handbook\%20\%20FINAL\%20December\%202019\%20v1.1.pdf

Scott, S. McNeish, D. Bovarnick, S \& Pearce, J (2019), What works in responding to child sexual exploitation, Ilford, Barnados

Senker, S., Scott, M., and Wainwright, L. (2020) An explorative study on perpetrators of child sexual exploitation convicted alongside others. London, Independent Inquiry into Child Sexual Abuse/Crown Copyright. Available at: https://www.iicsa.org.uk/key-documents/18725/view/explorative-studyperpetrators-child-sexual-exploitation-convicted-alongside-others-may-2020.pdf

Social Care Institute for Excellence (2012) Personalisation: A Rough Guide.' London SCIE. Available at: https://www.scie.org.uk/personalisation/introduction/rough-guide

Stanley, T, (2017) 'Working more reflexively with risk: holding 'signs of safety and wellbeing' in mind', in Cooper, A. and White, E. (eds), Safeguarding Adults Under the Care Act: Understanding Good Practice, London, Jessica Kingsley Publications, pp. 40-56.

Taylor, M. and Tapper, L. (2017), 'Participative Practice and Family Group Conferencing' in Cooper, A. and White, E. (eds), Safeguarding Adults Under the Care Act: Understanding Good Practice, London, Jessica Kingsley Publications, pp. 57-73.

Thomas, N. and Percy-Smith, B. (2012), 'It's about changing services and building relationships': evaluating the development of Children in Care Councils. Child \& Family Social Work, 17: pp.487496.

Treisman, K. (2017) Working with relational and developmental trauma in children and adolescents. London, Routledge.

Tucker, F. (2016) Developing Autonomy and Transitional Paternalism. Bioethics, 30: pp.759-766.

Turnell, A. and Edwards, S. (1999) Signs of safety: A solution and safety oriented approach to child protection casework. W.W. Norton and Company, London

Turner, A., Belcher, L., and Pona, I. (2019) Counting Lives: responding to children who are criminally exploited. London, The Children's Society. Available at:

https://www.childrenssociety.org.uk/sites/default/files/2020-10/counting-lives-report.pdf

United Nations (2020) Youth, Available at: https://www.un.org/en/sections/issues-depth/youth-0/

Wallace, M and Cocker, C (forthcoming - 2021) 'Following the death of Ms A'. Practice: Social Work in Action: Special Issue on Transitional safeguarding.

Warrington, C. (2016) Young person-centred approaches in child sexual exploitation (CSE) promoting participation and building self-efficacy. Dartington, Research in Practice.

White, E. (2017) 'Assessing and Responding to Risk' in Cooper, A. and White, E. (eds), Safeguarding Adults Under the Care Act: Understanding Good Practice, London, Jessica Kingsley Publications, pp. 110-127. 
Table 1: List of key legislation

\begin{tabular}{|c|c|}
\hline Legislation & Summary \\
\hline $\begin{array}{l}\text { Local Authority Social } \\
\text { Services Act } 1970\end{array}$ & $\begin{array}{l}\text { Primary legislation that brought about the creation, organisation, } \\
\text { management and administration of local authority social services } \\
\text { departments in England in the 1970s. }\end{array}$ \\
\hline Human Rights Act 1988 & $\begin{array}{l}\text { Outlines the rights and freedoms guaranteed under the European } \\
\text { Convention on Human Rights and made those rights enforceable in UK } \\
\text { courts. }\end{array}$ \\
\hline Children Act 1989 & $\begin{array}{l}\text { Outlines the law relating to children, centring on the idea children are } \\
\text { best cared for within their own families where this is possible. It } \\
\text { introduced the principle of 'parental responsibility' rather than } \\
\text { 'parental rights', and a number of core decision-making principles. (see } \\
\text { table 2). The Act placed importance on prevention in its allocation of } \\
\text { duties to local authorities. It also provided duties to local authorities, } \\
\text { courts, parents, and other agencies in the United Kingdom, in } \\
\text { the safeguarding of children and the promotion of their welfare. }\end{array}$ \\
\hline $\begin{array}{l}\text { Mental Capacity Act } \\
2005\end{array}$ & $\begin{array}{l}\text { Contains legal provisions to protect and empower people who lack } \\
\text { mental capacity to make key decisions in their lives. }\end{array}$ \\
\hline Mental Health Act 2007 & $\begin{array}{l}\text { Defines how people with serious mental health conditions should be } \\
\text { assessed and treated, including during their admission to hospital or } \\
\text { any other mental health facility and aftercare services. Outlines the } \\
\text { rights of people with serious mental illnesses who are affected by this } \\
\text { legislation. }\end{array}$ \\
\hline $\begin{array}{l}\text { Deprivation of Liberty } \\
\text { Safeguards (soon to be } \\
\text { Liberty and Protection } \\
\text { Safeguards) }\end{array}$ & $\begin{array}{l}\text { Deprivation of Liberty Safeguards (DoLS) provides the procedure } \\
\text { prescribed in the Mental Capacity Act } 2005 \text { when it is necessary to } \\
\text { deprive someone of their liberty, where they lack capacity to consent } \\
\text { to their care and treatment, in order to keep them safe from harm. The } \\
\text { Mental Capacity (Amendment) Act } 2019 \text { replaces DoLS with the Liberty } \\
\text { Protection Safeguards (LPS), which are due to be implemented in 2021, } \\
\text { streamlining and changing the process. }\end{array}$ \\
\hline Equality Act 2010 & $\begin{array}{l}\text { Provides legal protections for those with 'protected characteristics' } \\
\text { from discrimination in the workplace and in wider society. }\end{array}$ \\
\hline Care Act 2014 & $\begin{array}{l}\text { Outlines provision for the assessment of care and support for adults } \\
\text { and carers; and safeguarding adults from abuse or neglect. }\end{array}$ \\
\hline $\begin{array}{l}\text { Children and Families } \\
\text { Act } 2014\end{array}$ & $\begin{array}{l}\text { Introduced a new system to help children with special educational } \\
\text { needs and disabilities including planning for transition to adulthood } \\
\text { (until 25), and enabled care leavers to have a choice to stay with their } \\
\text { foster families until their 21st birthday. }\end{array}$ \\
\hline $\begin{array}{l}\text { Children and Social } \\
\text { Work Act } 2017\end{array}$ & $\begin{array}{l}\text { Requires Local Authorities to publish information about their services } \\
\text { to care leavers, including to offer advice and support to all care } \\
\text { experienced people up to the age of } 25 \text {. }\end{array}$ \\
\hline $\begin{array}{l}\text { Homelessness } \\
\text { Reduction Act } 2017\end{array}$ & $\begin{array}{l}\text { Places duties on housing authorities to prevent homelessness and } \\
\text { relieve homelessness for all eligible applicants, not just those that have } \\
\text { priority need under the Housing Act. }\end{array}$ \\
\hline
\end{tabular}


Table 2: Comparison of Safeguarding Principles for Adults and Children in England with the Making Safeguarding Personal 'l' statements:

\begin{tabular}{|c|c|c|}
\hline $\begin{array}{l}\text { Safeguarding Principles for } \\
\text { Adults (14.13 Care And Support } \\
\text { Statutory Guidance 2020) }\end{array}$ & $\begin{array}{l}\text { MSP 'I' statements (Care and } \\
\text { Support Statutory Guidance 2020) }\end{array}$ & $\begin{array}{l}\text { Safeguarding Principles for } \\
\text { Children (Children Act 1989) }\end{array}$ \\
\hline Wellbeing of the adult & & Welfare of the child \\
\hline $\begin{array}{l}\text { Proportionality: The least } \\
\text { intrusive response appropriate } \\
\text { to the risk presented. }\end{array}$ & $\begin{array}{l}\text { 'I am sure that the professionals } \\
\text { will work in my interest, as I see } \\
\text { them and they will only get } \\
\text { involved as much as needed.' }\end{array}$ & $\begin{array}{l}\text { Three overarching principles: } \\
\text { - paramountcy of the } \\
\text { welfare of the child; } \\
\text { 'no order' principle - there } \\
\text { is some cross-over with } \\
\text { proportionality principle in } \\
\text { adult safeguarding; } \\
\text { - 'no delay' principle. } \\
\text { Human Rights Act } 1998 \text { also } \\
\text { requires a proportional approach } \\
\text { when Article } 8 \text { right to private and } \\
\text { family life is qualified. For children } \\
\text { and adults, one must intervene only } \\
\text { as much as is necessary to achieve } \\
\text { a safeguarding goal. }\end{array}$ \\
\hline $\begin{array}{l}\text { Protection: Support and } \\
\text { representation for those in } \\
\text { greatest need. }\end{array}$ & $\begin{array}{l}\text { 'I get help and support to report } \\
\text { abuse and neglect. I get help so } \\
\text { that I am able to take part in the } \\
\text { safeguarding process to the extent } \\
\text { to which I want.' }\end{array}$ & $\begin{array}{l}\text { Protection: From serious harm } \\
\text { (s47); }\end{array}$ \\
\hline $\begin{array}{l}\text { Prevention: It is better to take } \\
\text { action before harm occurs. }\end{array}$ & $\begin{array}{l}\text { 'I receive clear and simple } \\
\text { information about what abuse is, } \\
\text { how to recognise the signs and } \\
\text { what I can do to seek help.' }\end{array}$ & $\begin{array}{l}\text { Preservation: Every effort should } \\
\text { be made to preserve the child's } \\
\text { home and family links; } \\
\text { a duty for and provision of services } \\
\text { to children in need (s17). }\end{array}$ \\
\hline $\begin{array}{l}\text { Empowerment: People being } \\
\text { supported and encouraged to } \\
\text { make their own decisions and } \\
\text { informed consent. }\end{array}$ & $\begin{array}{l}\text { 'I am asked what I want as the } \\
\text { outcomes from the safeguarding } \\
\text { process and these directly inform } \\
\text { what happens.' }\end{array}$ & $\begin{array}{l}\text { Participation: The views of children } \\
\text { should be sought according to their } \\
\text { age and understanding; }\end{array}$ \\
\hline $\begin{array}{l}\text { Accountability: Accountability } \\
\text { and transparency in delivering } \\
\text { safeguarding. }\end{array}$ & $\begin{array}{l}\text { 'I understand the role of everyone } \\
\text { involved in my life and so do they.' }\end{array}$ & $\begin{array}{l}\text { Accountability: No equivalent for } \\
\text { children's safeguarding practice. }\end{array}$ \\
\hline $\begin{array}{l}\text { Partnership: Local solutions } \\
\text { through services working with } \\
\text { their communities. } \\
\text { Communities have a part to play } \\
\text { in preventing, detecting and } \\
\text { reporting neglect and abuse. }\end{array}$ & $\begin{array}{l}\text { 'I know that staff treat any } \\
\text { personal and sensitive information } \\
\text { in confidence, only sharing what is } \\
\text { helpful and necessary. I am } \\
\text { confident that professionals will } \\
\text { work together and with me to get } \\
\text { the best result for me.' }\end{array}$ & $\begin{array}{l}\text { Partnership: Services should work } \\
\text { in partnership with parents and } \\
\text { others with Parental Responsibility }\end{array}$ \\
\hline
\end{tabular}


Figure 1: Legislation relevant to young people

\begin{tabular}{|l|l|l|l|l|l|l|l|l|l|l|l|}
\hline Age & 15 & 16 & 17 & 18 & 19 & 20 & 21 & 22 & 23 & 24 & 25 \\
\hline $\begin{array}{l}\text { Children Act 1989 } \\
\text { (looked after children) }\end{array}$ & & & & & & & & & & & \\
\hline Children Act 1989 (CP) & & & & & & & & & & & \\
\hline $\begin{array}{l}\text { Children and Social Work Act 2017 } \\
\text { (looked after children) }\end{array}$ & & & & & & & & & & & \\
\hline Mental Capacity Act 2005 & & & & & & & & & & & \\
\hline Mental Health Act 2007 & & & & & & & & & & & \\
\hline $\begin{array}{l}\text { Deprivation of Liberty Safeguards } \\
\text { (DOLS) }\end{array}$ & & & & & & & & & & & \\
\hline Care Act 2014 & & & & & & & & & & & \\
\hline $\begin{array}{l}\text { Children \& Families Act 2014 } \\
\text { (SEND) }\end{array}$ & & & & & & & & & & & \\
\hline
\end{tabular}

Key:

Is relevant to age as indicated

Is partially relevant to age as indicated

Is not relevant to age as indicated 
Figure 2: Mind the Gap: Young People who may have transitional safeguarding needs

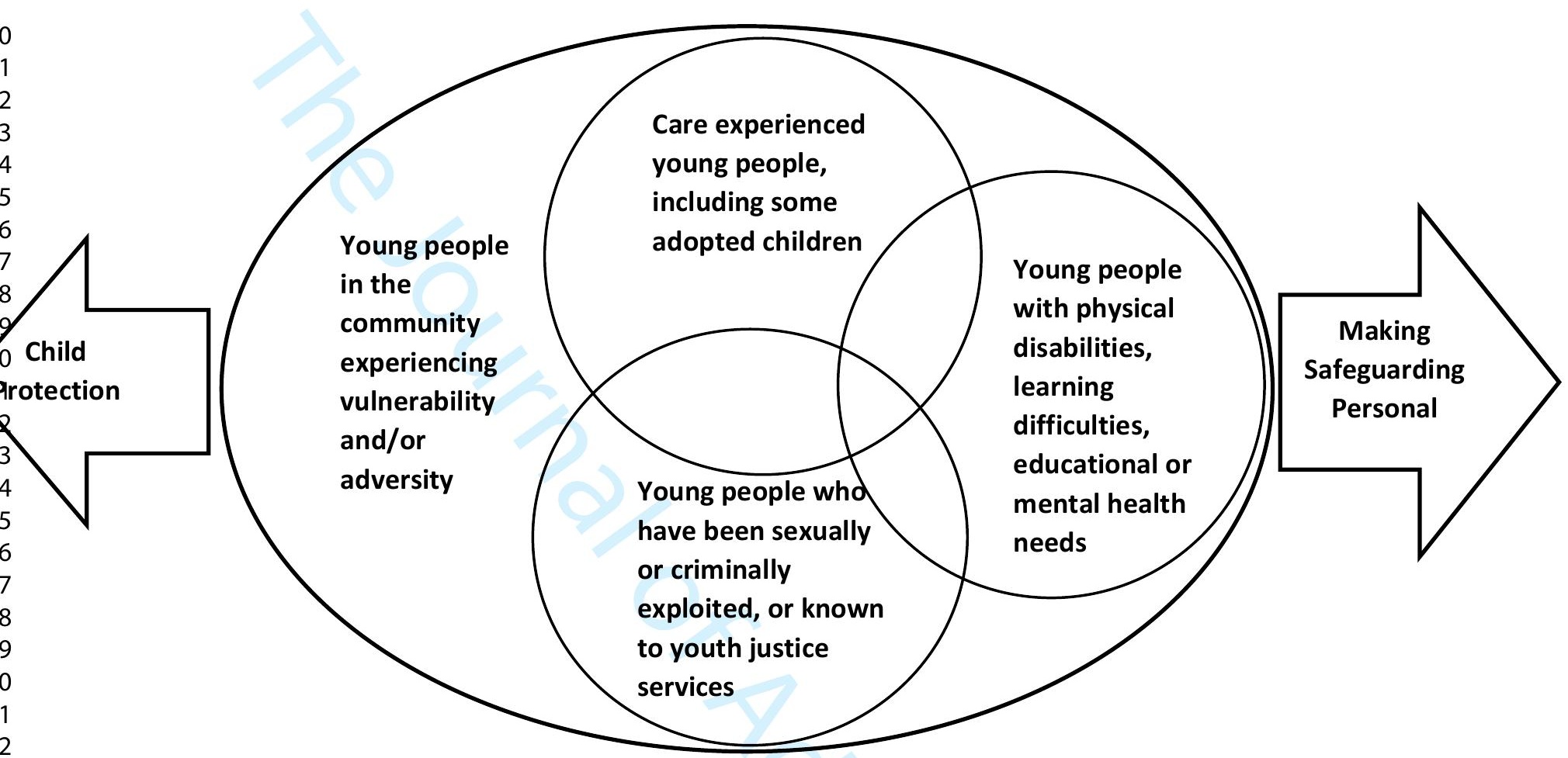

